ISSN 0258-7122

Bangladesh J. Agril. Res. 35(2) : 247-255, June 2010

\title{
YIELD AND STORABILITY OF ONION (Allium cepa L.) AS AFFECTED BY VARYING LEVELS OF IRRIGATION
}

\author{
S.K. BISWAS ${ }^{1}$, A. KHAIR ${ }^{2}$, P.K. SARKER ${ }^{3}$ \\ AND M.S. ALOM ${ }^{4}$
}

\begin{abstract}
Bulb yield and storability of onions (cv. BARI Piaj-1) was studied against five levels of irrigation viz., no irrigation, irrigation at 10,15, 20, and 30 days interval. Yield and storage losses were increased gradually with increasing number of irrigation. The highest yield of onion was obtained with a total of six irrigations at 10 days interval and it was at par with treatment that received four irrigations at 15 days intervals. Losses due to rotting, sprouting, and physiological weight loss were found higher in irrigated treatments. After six months of storage (from $1^{\text {st }}$ week of April to 1 st week of October), the maximum cumulative weight loss (56.72\%) was recorded in onions irrigated at 10 days interval, while the minimum (46.80\%) was recorded in non-irrigated onions.
\end{abstract}

Keywords : Storability, onion bulb, irrigation, storage losses.

\section{Introduction}

Among the spice crops, onion (Allium cepa L.) ranks second in terms of area coverage (37,560 hectares) but attains top in production (153,000 m.tons) covering about $15 \%$ of total area under spices and condiments (BBS, 2004). It is grown all over Bangladesh mostly in the winter season and is stored for consumption throughout the year. After getting a good harvest of onion, farmers face storage problems in all conditions. Being a semi-perishable crop, it is subjected to deterioration during storage. Storage loss of onions is caused by rotting, sprouting, and physiological weight loss. Rabbani et al. (1986) reported that storage losses in onion could be as high as $66 \%$. Many factors, such as cultivars, bulb maturity, moisture content of the bulb, temperature, relative humidity, etc. are associated with spoilage of onion during storage. Thus, irrigation may have some effect on storability of onion as it helps increase moisture content of bulb (Chung, 1989). Many authors investigated the effect of irrigation on onion yield, but the literature revealed scanty information about the effect of irrigation on storage of onion. Soujala et al. (1998) reported that irrigation had only a minor effect on the storage performance and shelf life of

\footnotetext{
${ }^{1}$ Senior Scientific Officer, ${ }^{3}$ Principal Scientific Officer, Irrigation and Water Management Division, Bangladesh Agricultural Research Institute (BARI), Joybebpur, Gazipur 1701, ${ }^{2}$ Professor, Dept. of Irrigation and Water Management, Bangladesh Agricultural University (BAU), Mymensingh 2202, ${ }^{4}$ Senior Scientific Officer, Agronomy Division, RARS, BARI, Jessore 7400, Bangladesh.
} 
onion. A substantial increase of decomposition in onion during storage with increasing irrigation was reported by Shock et al. (1998). Nandi et al. (2002) reported that growth and yield of onion were significantly affected by irrigation, but not post harvest life. The study was, therefore, undertaken with a view to finding out the effect of irrigation on yield and storability of onion.

\section{Materials and Method}

The experiment was conducted at the Regional Agricultural Research Station, Bangladesh Agricultural Research Institute (BARI), Jessore during the rabi season of 2003-2004. The soil of the experimental field was silty clay loam in texture having field capacity of 27.5 percent by weight and bulk density, 1.48 $\mathrm{g} / \mathrm{cc}$. The treatment consisted of five irrigation levels viz., no irrigation $\left(\mathrm{I}_{1}\right)$. irrigation at $10\left(\mathrm{I}_{2}\right), 15\left(\mathrm{I}_{3}\right), 20\left(\mathrm{I}_{4}\right)$, and $30\left(\mathrm{I}_{5}\right)$ days intervals. The experiment was laid out in a complete randomized block design with three replications. The unit plot size was $3 \mathrm{~m} \times 2 \mathrm{~m}$. The seedlings of onion were transplanted at $10 \mathrm{~cm}$ spacing in rows $20 \mathrm{~cm}$ apart on 30 December 2003. Fertilizer application rates were $\mathrm{N}_{120} \mathrm{P}_{100} \mathrm{~K}_{75} \mathrm{~S}_{30} \mathrm{~kg} / \mathrm{ha}$. One-third of $\mathrm{N}$ in the form of urea and full doses of $\mathrm{P}$, $\mathrm{K}$, and $\mathrm{S}$ in the form of triple super phosphate (TSP), muriate of potash (MP), and zypsum, respectively, were applied at the final land preparation. The remaining two-thirds of $\mathrm{N}$ were top-dressed in two equal splits at 25 and 50 days after planting (DAP). Soil moisture was monitored before irrigations by gravimetric method. Amount of irrigation water needed to bring the soil moisture to field capacity was calculated as per the formula below (Michael, 1978) and hence applied as per treatment.

$\mathrm{d}=\sum_{\mathrm{i}=1}^{\mathrm{n}} \frac{\mathrm{M}_{\mathrm{fci}}-\mathrm{M}_{\mathrm{bi}}}{100}$.Ai.Di

Where, $\mathrm{d}=$ net amount of water to be applied during an irrigation, $\mathrm{cm}$

$\mathrm{M}_{\mathrm{fci}}=$ field capacity moisture content by weight in the ith layer of the soil, \%

$\mathrm{M}_{\mathrm{bi}}=$ moisture content by weight before irrigation in the ith layer of the soil, \%

$\mathrm{A}_{\mathrm{i}}=$ apparent specific gravity i.e., numerical value of bulk density of the ith layer of the soil

$\mathrm{D}_{1}=$ depth of the ith layer of the soil within the rootzone, $\mathrm{cm}$, and

$\mathrm{n}$ = number of layers in the root zone

A common irrigation amounting thirty millimeters of water was applied just after transplanting of seedlings for plant establishment. Irrigation was stopped before 25 days of harvesting (Doorenbos and Kassam, 1979). 
The crop was harvested on 31 March 2004 when about $75-80 \%$ of the plants became matured. After harvest, bulbs were kept under a shade for 7 days for curing. Then, for storage studies, $15 \mathrm{~kg}$ bulbs from each treatment were taken, divided into 3 equal splits, each representing a replicate and stored on rack at room temperature for 180 days. The observations were done for sprouting, rotting, and total weight loss at 15 days intervals. The rotten bulbs from each treatment were sorted out at the time of recording the data. The temperature and relative humidity of the storage room were also recorded. The collected data on various parameters were statistically analyzed.

\section{Results and Discussion}

\section{Total water received and yield}

Irrigation water applied, total water used and bulb yield of onion are presented in Table 1. It is observed that the bulb yields are correlated with the number of irrigation and total water used. A quantum jump in bulb yield occurred with irrigation number and quantity. The bulb yield increase of the irrigated treatments over control ranged from 114.65 to as high as $252.95 \%$. However, there was a decreasing trend in rate of increasing yield with increasing the number of irrigation (Fig. 1). Treatment $I_{2}$ received a total of $205 \mathrm{~mm}$ irrigation water in six applications. It was followed by $\mathrm{I}_{3}$ which received a total of $184 \mathrm{~mm}$ of irrigation water in four applications.

Table 1. Irrigation water applied, water used and bulb yield of onion.

\begin{tabular}{l|c|c|c|c|c|c|c|c}
\hline & $\begin{array}{c}\text { No. of } \\
\text { Irri. after } \\
\text { Trop } \\
\text { establish- } \\
\text { ment }\end{array}$ & $\begin{array}{c}\text { Water } \\
\text { applied } \\
\text { for plant } \\
\text { establish- } \\
\text { ment } \\
(\mathrm{mm})\end{array}$ & $\begin{array}{c}\text { Water } \\
\text { applied } \\
\text { after plant } \\
\text { establish- } \\
\text { ment } \\
(\mathrm{mm})\end{array}$ & $\begin{array}{c}\text { Total } \\
\text { water } \\
\text { applied } \\
(\mathrm{mm})\end{array}$ & $\begin{array}{c}\text { Soil } \\
\text { mois- } \\
\text { ture } \\
\text { deficit } \\
(\mathrm{mm})\end{array}$ & $\begin{array}{c}\text { Rain- } \\
\text { fall } \\
(\mathrm{mm})\end{array}$ & $\begin{array}{c}\text { Total } \\
\text { water } \\
\text { used } \\
(\mathrm{mm})\end{array}$ & $\begin{array}{c}\text { Bulb } \\
\text { yield } \\
(\mathrm{t} / \mathrm{ha})\end{array}$ \\
\hline $\mathrm{I}_{1}$ & 0 & 30 & 0 & 30 & 54 & 2.7 & 86.7 & $3.55 \mathrm{c}$ \\
$\mathrm{I}_{2}$ & 6 & 30 & 175 & 205 & 31 & 2.7 & 238.7 & $12.53 \mathrm{a}$ \\
$\mathrm{I}_{3}$ & 4 & 30 & 154 & 184 & 33 & 2.7 & 219.7 & $12.13 \mathrm{a}$ \\
$\mathrm{I}_{4}$ & 3 & 30 & 135 & 165 & 34 & 2.7 & 201.7 & $10.27 \mathrm{ab}$ \\
$\mathrm{I}_{5}$ & 2 & 30 & 107 & 137 & 36 & 2.7 & 175.7 & $7.62 \mathrm{~b}$ \\
\hline
\end{tabular}

Values with the same letter are statistically similar at $5 \%$ level of significance

Bulb yield of onion showed significant variation among the treatments. As $\mathrm{I}_{1}$ received no irrigation, yield was the lowest (3.55 t/ha). Treatment $I_{2}$ received maximum number of irrigations and produced the highest yield (12.53 t/ha). The yield of bulb increased almost linearly with increasing number of irrigation. Treatment $\mathrm{I}_{2}$ did not differ significantly with $\mathrm{I}_{3}$ and $\mathrm{I}_{4}$ in this regard. 


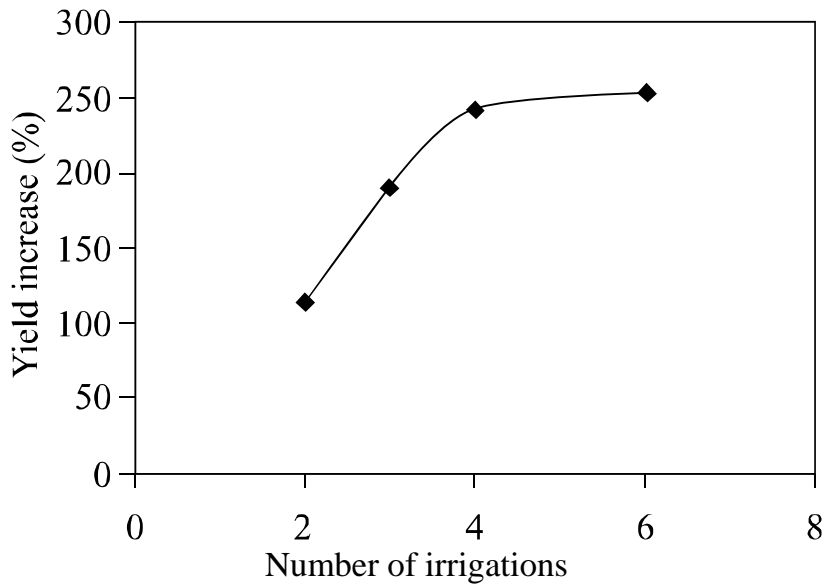

Fig. 1. Yield increase over control by varying levels of irrigation.

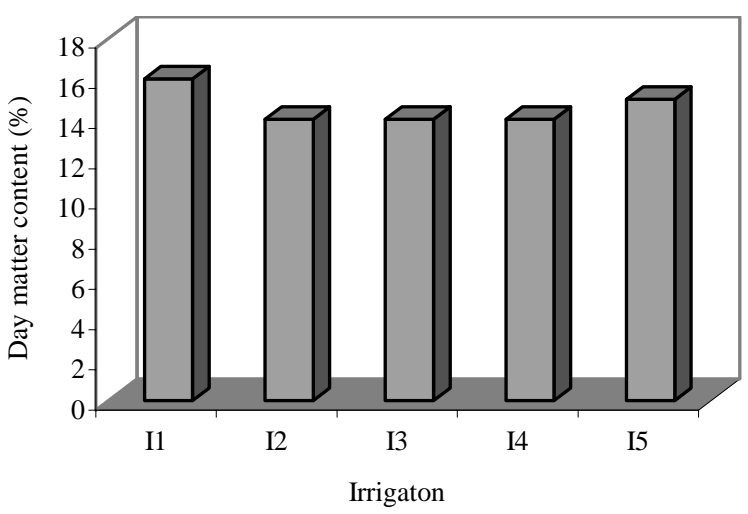

Fig. 2. Change in dry matter content of onion bulb with irrigation.

\section{Dry matter content of bulb}

Dry matter content of bulbs showed a decreasing trend with increasing level of irrigation (Fig. 2). The maximum dry matter percentage (16.12\%) was recorded in bulbs of the non-irrigated treatment $I_{1}$ followed by that (15.09\%) of treatment $1_{5}$ which received irrigation at 30 days interval. However, dry matter percentage was found minimum (13.91\%) in $\mathrm{I}_{2}$ which received irrigation at 10 days interval. This result is in agreement with the findings of Chung (1989) who reported that irrigation has a trend to decrease the bulb dry matter content.

\section{Effect of irrigation on storage losses}

Different kinds of losses of onion under different levels of irrigation during storage period have been presented graphically in Fig. 3a to 3d. The data 
pertaining to rotting, sprouting, and total weight loss over 180 days have been presented in Table 2.

Table 2. Storage losses of onion after 180 days of storage.

\begin{tabular}{l|l|l|l|l}
\hline $\begin{array}{c}\text { Irrigation } \\
\text { treatment }\end{array}$ & $\begin{array}{c}\text { Rotted onion } \\
(\%)\end{array}$ & $\begin{array}{c}\text { Sprouted onion } \\
(\%)\end{array}$ & $\begin{array}{c}\text { Physiological wt } \\
\text { loss (\%) }\end{array}$ & $\begin{array}{c}\text { Total storage } \\
\text { loss (\%) }\end{array}$ \\
\hline $\mathrm{I}_{1}$ & $14.73 \mathrm{c}$ & $5.82 \mathrm{~b}$ & $26.25 \mathrm{~d}$ & $46.80 \mathrm{c}$ \\
$\mathrm{I}_{2}$ & $20.59 \mathrm{a}$ & $6.80 \mathrm{a}$ & $29.33 \mathrm{a}$ & $56.72 \mathrm{a}$ \\
$\mathrm{I}_{3}$ & $20.86 \mathrm{a}$ & $5.97 \mathrm{a}$ & $29.17 \mathrm{a}$ & $56.00 \mathrm{a}$ \\
$\mathrm{I}_{4}$ & $16.92 \mathrm{~b}$ & $5.96 \mathrm{~b}$ & $27.28 \mathrm{~b}$ & $50.16 \mathrm{~b}$ \\
$\mathrm{I}_{5}$ & $15.20 \mathrm{c}$ & $5.75 \mathrm{~b}$ & $26.98 \mathrm{c}$ & $47.91 \mathrm{bc}$ \\
\hline
\end{tabular}

Means having same letter do not differ significantly at 5\% level of probability

\section{Rotting}

The bulbs started rotting after 75 days of storage. Percentage of rotten bulbs of onion was significantly influenced by different levels of irrigation (Fig. 3a). Losses due to rotting of bulbs of treatments $\mathrm{I}_{2}$ and $\mathrm{I}_{3}$ (irrigation at 10 days and 15 days interval, respectively) were higher and identical during 180 days of storage period. The lowest rotting was found in non-irrigated treatment $\left(\mathrm{I}_{1}\right)$ and differed insignificantly with that of $I_{5}$ which received only two irrigations at 30 days intervals. This result corresponds the earlier findings of Shock et al. (1998) who reported substantial increase of decomposition of onion during storage with increasing irrigation threshold. From $90^{\text {th }}$ to $105^{\text {th }}$ days of storage, irrespective of treatment, rotting losses were more or less the same. The lowest rotting loss in the control treatment may be due to the fact that control plots did not receive any irrigation that kept the bulbs less succulent and as a result less attacked by bacteria and fungi during storage.

\section{Sprouting}

Sprouting behaviour of onion under different irrigation levels has been shown in Fig. 3b. The bulbs started sprouting after 90 days of storage. Sprouting was significantly higher after 180 days of storage in the onions of treatment $\mathrm{I}_{2}$ with a little exception in 105 days of storage when sprouting in treatment $\mathrm{I}_{3}$ was a little bit higher. The lowest sprouting was observed in non-irrigated treatment $\mathrm{I}_{1}$ during the entire storage period. A little deviation after 165 days of storage was observed in this treatment, but it was identical with $\mathrm{I}_{3}, \mathrm{I}_{4}$, and $\mathrm{I}_{5}$. It indicates that irrigation has minor or no effect on sprouting of onion. The higher percentage of sprouting in the treatments that received higher number of irrigation may be due to slightly higher moisture content in the bulbs of these treatments. Thompson et al. (1972) reported that the onion bulbs are naturally dormant at maturity and the 
length of this dormant period varies with the cultivar and conditions under which the bulbs were grown and stored. Salunkhe and Desai (1984) described sprouting as a normal physiological change in stored bulbs that develops reproductive shoots in the second year. Irrigation, thus, has little effect on sprouting.

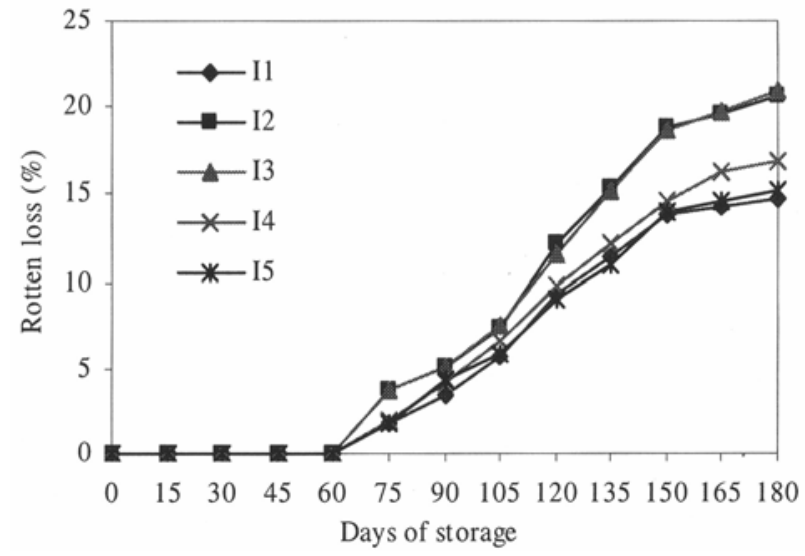

Fig. 3a. Rotten loss of onion during storage

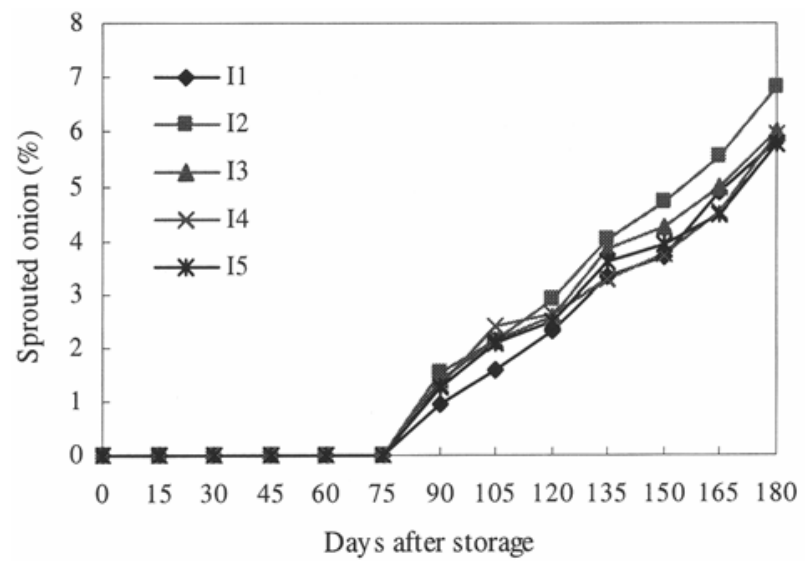

Fig. 3b. Sprouting of onion during storage

\section{Physiological weight loss}

The highest physiological loss in weight was observed in $\mathrm{I}_{2}$ and $\mathrm{I}_{3}$ during the whole period (Fig. 3c). In all the treatments, in general, weight loss was higher in the first month, thereafter; it reduced with a little exception from 60th to 75th days when weight loss was the highest in $\mathrm{I}_{2}$ and $\mathrm{I}_{3}$. The higher weight loss in the first month might be due to higher initial moisture content of the bulbs at the onset of the experiment and during 60th to 75th days, the weight loss increased (in $\mathrm{I}_{2}$ and $\mathrm{I}_{3}$ ) as a result of rotting and sprouting during this period. This result agrees with the findings of Chung (1989) who reported that irrigation increased 
the level of wastage during storage. Weight loss was found higher in treatment $\mathrm{I}_{2}$ and $\mathrm{I}_{3}$ than those of other treatments during the whole period of storage.

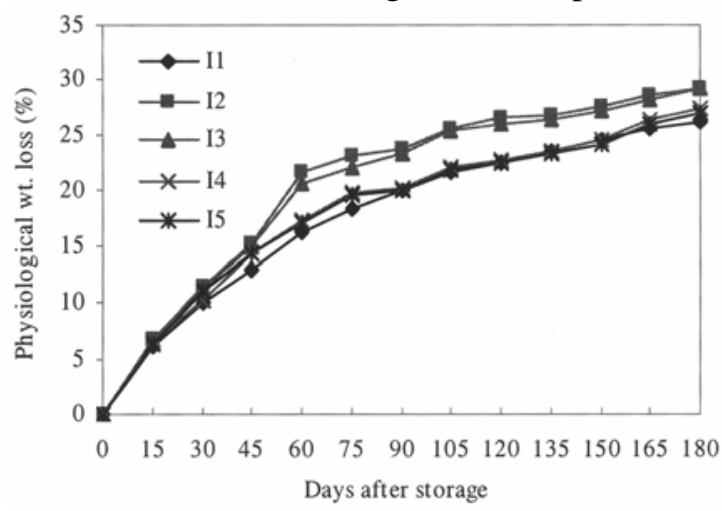

Fig. 3c. Physiological weight loss of stored onion

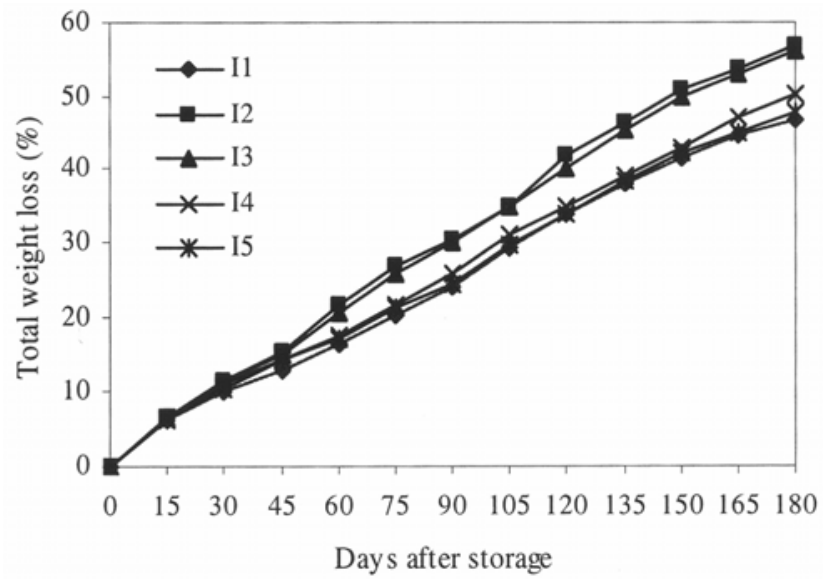

Fig. 3d. Total weight loss of onion during storage

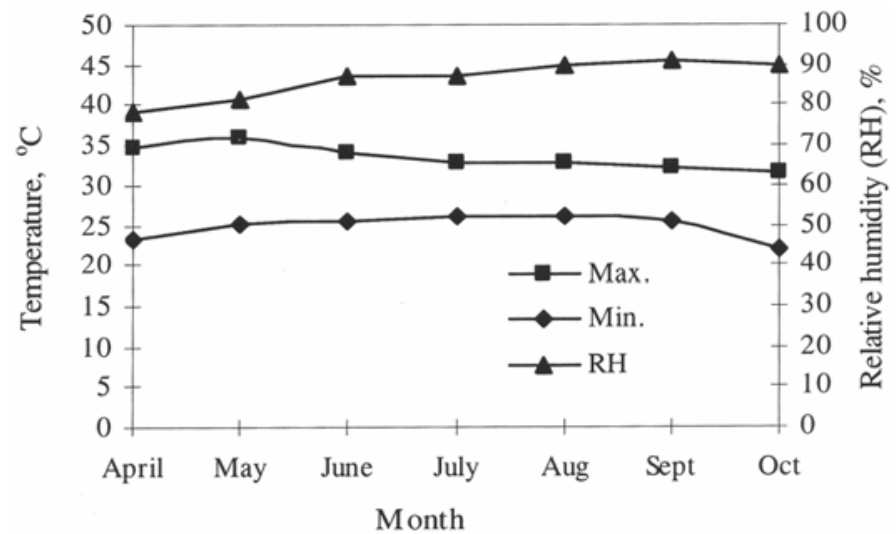

Fig. 4. Monthly average temperature and relative humidity during the storage of onion 


\section{Total storage loss}

Storage loss of bulb was found highest (56.72\%) in treatment $\mathrm{I}_{2}$ (irrigation at 10 days interval) and it was identical with $\mathrm{I}_{3}(56.0 \%)$ which received irrigation at 15 days interval (Table 2). The lowest storage loss (46.80\%) was recorded in nonirrigated treatment. This was followed insignificantly by $\mathrm{I}_{5}$ (irrigation at 30 days interval) where $47.91 \%$ of onion was lost during storage.

The percentage of weight loss of stored bulbs was significantly influenced by irrigation (Fig. 3d). In periodical observation of 15 days intervals, it was found that the stored onion of all treatments lost weight gradually during the whole period of storage and after 180 days of storage, maximum weight loss (56.72\%) was recorded in $\mathrm{I}_{2}$ (irrigation at 10 days interval) and it was identical with that (56.0\%) of $\mathrm{I}_{3}$ (irrigation at 15 days interval). The minimum weight loss (46.80\%) was found in onion of non-irrigated treatment $\mathrm{I}_{1}$ and it was statistically identical with $I_{5}$ which received irrigation at 30 days interval. Weight loss of onion bulbs is usually known to occur due to rotting, sprouting, dehydration, transpiration, respiration, etc. and it is generally caused due to prevailing high temperature and high humidity in the environment. It has been observed that although high humidity effectively reduced weight loss, it favoured fungal development, especially at higher temperature (Shippers, 1968). Aoyagi et al. (1977) described that decay of bulbs is increased with increase in temperature. In the present study, temperature and humidity were high during storage (Fig. 4) that might be attributed to the higher weight loss of stored onions.

\section{Conclusions}

Irrigation, both at 10 and 15 days interval, gave the maximum yields which were identical with each other. The storage losses of onion were found to increase gradually with increasing number of irrigation, but the increase in bulb yield was found to be insignificant when irrigation interval was less than 15 days. Therefore, it may be concluded that if onion bulbs are to be used fairly quickly, then maximum yield can be achieved by increasing the number of irrigation; but if they are to be stored for a long time in normal storage condition, the number of irrigations can be decreased to three. However, further study should be done to assess an economic analysis after six months' storage to determine the level of irrigation more profitable for onion yield and storage.

\section{References}

Aoyagi, M., H. Makio and T. Sato. 1997. The effect of storage temperature on the keeping quality of onion bulbs. Res. Bull. Aichiken Agric. Res. Cen. B. (Horticulture). No. 7: 54-60.

BBS. 2004. Statistical Yearbook of Bangladesh. Bangladesh Bureau of Statistics, Ministry of Planning, Govt. of the People’s Republic of Bangladesh, Dhaka. 
Chung, B. 1989. Irrigation and bulb onion quality. Acta- Horticulturae, 247: 233-237.

Doorenbos, J. and A.H. Kassam. 1979. Yield response to water. FAO Irrigation and Drainage Paper No. 33. Rome, Italy.

Michael, A.M. 1978. Irrigation Theory and Practice. Vikas Publishing House Pvt. Ltd., New Delhi, 801p.

Nandi, R.K., M. Deb, T.K. Maity and G. Sounda. 2002. Response of onion to different levels of irrigation and fertilizer. Crop Research Hisar. 23(2): 317-320.

Rabbani, M.G., A. Hussain, M.A. Siddique and A.H.M. Faruque. 1986. Yield and storability of seven onion (Allium cepa L.) cultivars. Bangladesh J. Agric. 11(4): 1-7.

Salunkhi, D.K. and B.B. Desai. 1984. Postharvest biotechnology of vegetables. Vol. II., CRC Press, Inc. Boca Raton, Florida. pp. 23-34.

Shippers, P.A. 1968. A preliminary experiment for weight loss in onions. N.Z. Comm. Grow. 23(10): 23-29.

Shock,C.C., E.B.G. Feibert and L.D. Saunders. 1998. Onion yield and quality affected by soil water potential as irrigation threshold. Hort. Science. 33(7): 1188-1191.

Soujala, T., T. Salo and R. Pessala. 1998. Effects of fertilization and irrigation practices on yield, maturity and storability of onions. Agricultural and Food Science in Finland. 7(4): 477- 489.

Thomson, A.K., R.H. Booth and F.L. Proctor. 1972. Onion storage in the tropics. Tropical Science 14(1): 19. 